\title{
Effect of Maize Hybrid Maturity and Grain Hardness on Fumonisin and Zearalenone Contamination
}

\author{
Massimo Blandino*, Amedeo Reyneri \\ Dipartimento di Agronomia, Selvicoltura e Gestione del Territorio, Università di Torino, \\ via Leonardo Da Vinci 44, 10095 Grugliasco (TO), Italy
}

Received: 11 March 2008. Accepted: 25 July 2008.

\begin{abstract}
The level of resistance in commercial hybrids for Fusarium ear rot is still not in general adequate to prevent unacceptable toxin concentrations in field. The purpose of this experiment was to verify the behaviour of commercial dent maize hybrids for fumonisin and zearalenone contamination and to identify the variety traits that influence the production of these toxins.

Field experiments were carried out in 2000, 2001 and 2002 to evaluate the effect of maize hybrid maturity and endosperm hardness on European Corn Borer (ECB) incidence, fungal ear rot incidence and severity and on fumonisin $B_{1}$ and zearalenone contents. Nineteen yellow soft commercial hybrids, from the 500, 600 and 700 FAO maturity groups, were compared in 4 sites in NW Italy. Hybrid were grouped in 3 endosperm hardness categories (hard, intermediate, soft) in function of Hard/Soft (H/S) endosperm ratio.

No effect due to endosperm hardness or hybrid maturity on the ECB infestation or fungal ear rot incidence and severity was observed.

Grain hardness significant influenced fumonisin $\mathrm{B}_{1}$ content: hard endosperm hybrids showed $50 \%$ lower contamination than soft hybrids. The presence of fumonisin $B_{1}$ in the grain of different maturity hybrids only resulted to be significantly different in 2001 experiment, with a mean concentration 2 times higher in the later hybrids (FAO rating 700) compared to the medium and medium-late hybrids.

The zearalenone content never resulted to be significantly different in function of the endosperm hardness, while, late maturing hybrids, in which grain moisture content decreases slowly below $30 \%$, are more susceptible to zearalenone contamination.

This research has highlighted the presence of variety traits that can influence mycotoxin contamination. An accurate choice of hybrid, considering the territorial and cultivation context, could contribute to achieve products, that contain mycotoxins, which do not exceed the maximum international and UE regulation levels.
\end{abstract}

Key-words: fumonisin, Fusarium ear rot, hybrid, maize, mycotoxins, zearalenone.

\section{Introduction}

Mycotoxins, secondary metabolites of several fungi, are toxic to animals and humans because they can be found in a large variety of foods and feeds (D'Mello and Mac Donald, 1997; Bilgrami and Choudhary, 1998; Chelkowski, 1998). Among cereals, maize is the most commonly contaminated, mainly through ear infections during crop cultivation (Logrieco, 2001; Moretti et al., 2003; Pietri et al., 2004).

In South and Central Europe, the most common toxigenic field fungi, that are able to accumulate toxic metabolites in the grain before harvesting, belong to the Fusarium genus. This genus include in particular F. verticillioides (Saccardo) Nirenberg (= F. moniliforme Sheldon, teleomorf = Gibberella subglutinans (Edwards) Nelson, Toussoun et Marasas) producers of fumonisins (Bacon and Nelson, 1994; Dutton, 1996; Visconti et al., 1999) and F. graminearum Schwabe (teleomorf = Gibberella zeae (Schwein.) Petch), producers of zearalenone and trichothecenes (Sutton, 1982; Manka et al., 1989; Visconti et al., 1990).

At present time two approaches are known to reduce infections and mycotoxin accumulation in the field: pre-harvesting control strategies, which consist of crop practices designed to reduce the infection and the development of

\footnotetext{
* Corresponding Author: Tel.: +39 011 6708895; Fax: +39 011 6708798. E-mail address: massimo.blandino@unito.it
} 
toxingenics fungi (Brown et al., 1998; AA.VV., 2004; Nicholson et al., 2004) and the utilization of genetically resistant hybrids or the identification of variety traits that are unfavourable for fungal development and toxinogenes (Duvick, 2001; Munkvold, 2003a).

Hybrid selection during the breeding process usually eliminates very susceptible genotypes, therefore commonly grown hybrids are not excessively susceptible (Munkvold, 2003a). Unfortunately hybrids with a high resistance to this pathology are not yet available on the market, as the process involved in the identification of natural resistances is complicated and costly, due to the necessity of carrying out inoculations of the pathogens and the analysis costs of the toxin content (Miedaner, 2004). In spite of these difficulties, much progress has been made in the identification of genetic resistance characteristics, especially against Gibberella and Aspergillus ear rot (Gorman et al., 1992; Brown et al., 1999; Hamblin and White, 2000; Vigier et al., 2001).

Several aspects of Gibberella ear rot resistance have been studied: Koehler (1959) and Enerson and Hunter (1980) demonstrated that correlations exist between Gibberella ear rot resistance and certain physical traits, such as husk tightness and the tendency of ears to remain upright. Assabgui et al. (1993) observed that there is a lower incidence of $F$. graminearum infection in hybrids with high concentrations of E-ferulic acid in the grain, Reid et al. (1992; 1994) identified a major gene which is responsible for the resistance to infection of $F$. graminearium through the silks, while Chungu et al. (1996) showed that resistance to silk infections and resistance to the subsequent diffusion of the pathogen in the kernels are under different genetic controls. Commercial hybrids that present these resistance mechanisms are not yet available, but some hybrids offered on the market show a partial resistance to Gibberella ear rot (Schaafsma et al., 1997; Payne, 1999).

The search for resistance to Fusarium ear rot, whose principal agent is $F$. verticillioides, is not so well documented in literature. Different susceptibility to Fusarium ear rot and different tendencies to accumulate fumonisins among commercial dent hybrids have been observed by Abbas et al. (2002), Pascale et al. (2002) and Kleinschmidt et al. (2005). The resistance sources that have been identified are polygenic and are therefore more difficult to incorporate in hybrids (Snijders, 1994, Clements et al., 2003). Scott and King (1984) and Headrick and Pataky (1991) determined that the resistance factors of grain to $F$. verticillioides are neither in the endosperm nor in the embryo, but are in the pericarp and that they are inherited from the female parent. Duvick et al. (1992) isolated a peptide of the maize grain that inhibited germination and hyphal development in vitro, while Warfield and Davis (1996) and Butròn et al. (2006) showed how hybrids with adherent and tight husks and less open apical parts of the ears, present more resistance to Fusarium ear rot. The presence of the opaque-2 gene (o2), which increases the lysine and tryptophan contents in the endosperm, has shown more susceptibility to infection from this pathogen (Warren, 1978), while waxy maize obtained by introducing the $w x$ gene is more prone to fumonisin accumulation compared to the counterpart hybrids (Blandino and Reyneri, 2007).

A recent approach to the search for hybrids that are resistant to mycotoxin contamination consists in the obtaining of genetically modified hybrids which create the resistance action through transgenes. At present it is possible to indirectly control contamination from fumonisins using Bt hybrids that are able to synthesise the transgenetic protein of Bacillus thuringiensis and which are active against European corn borer larvae (Munkvold et al., 1997; Munkvold et al., 1999; Masoero et al., 1999).

Genetic engineering for direct protection from mycotoxigenic fungi and their mycotoxins could be a valuable management strategy in the future, with the introduction of genes that codify according to protein or secondary metabolite with antifungal actions or genes that regulate the production of enzymes which are able to detoxificate the toxins. The most recent application concerns the insertion, into the maize genome, of genes that decodify for a fumonisin esterase, produced by a yeast, Exophiala spinifera (Blackwell et al., 1999), that is able to degrade the fumonisins; of a trichothecenes 3$\mathrm{O}$-acetyltransferase gene that is present in the F. graminearum genome (Okubara et al., 2002) and of $\alpha$-amylase, from another plant, Lablab purpureus (a legume) inhibited aflatoxin production, spore germination and hyphal growth by A. flavus (Woloshuk and Fakhoury, 2000).

The level of resistance in commercial hybrids 
for Gibberella and Fusarium ear rot is still not in general adequate to prevent unacceptable toxin concentrations in field (Snijders, 1994, Munkvold, 2003a). While waiting for hybrids with specific genetic resistance against these pathologies to appear on the market, and considering the actual necessary requirements of preventive systems that can guarantee a higher hygiene-health quality of the productions, it is however necessary to identify which morphological, physiological and physical characteristics of the grain of hybrids at present available on the market could be the most interesting for the containment of mycotoxins.

The purpose of this experiment was to verify the behaviour of some commercial dent maize hybrids with different maturity and grain hardness for fumonisin and zearalenone contamination and to identify the influence of this traits on the production of these toxins.

\section{Materials and methods}

\section{Experimental sites and treatments}

Mycotoxin contamination was evaluated in 19 commercial and commonly cultivated dent type maize hybrids from 2000 to 2002: 10 medium maturity hybrids (FAO rating 500), 6 mediumlate maturity hybrids (FAO rating 600) and 3 late maturity hybrids (FAO rating 700).

The yellow dent maize hybrids used for the experiment were grouped in 3 categories of grain hardness (soft, intermediate and hard) based on the hard to soft endosperm ratio $(\mathrm{H} / \mathrm{S}$ endosperm ratio), as reported by Li et al. (1996).

The H/S endosperm ratio in the grain samples was estimated by sectioning the kernels and measuring the areas of hard and soft endosperm presented at the cut surface. Dried kernels were sectioned just above the top of the embryo region using a pair of secateurs. The $\mathrm{H} / \mathrm{S}$ ratios for 10 kernels of each sample were calculated by measuring the area of the cut surface and the soft endosperm region, using their scanned images and a digital image processing (ImageJ software, version 1.38). Four hybrids showed a mean $\mathrm{H} / \mathrm{S}$ endosperm ratio higher than 4 and were classified as hard, while 6 hybrids showed values between 1 to 4 and were classified as intermediate. Hybrids with $\mathrm{H} / \mathrm{S}$ endosperm ratio value lower than 1 were classified as soft.
The experiments were carried out in the following sites:

- Carmagnola (44 50’ N, 7 40’ E; altitude 245 $\mathrm{m}$., in a sandy-medium textured soil (Typic Udifluvents);

- Giarole (45 $04^{\prime}$ N, $8^{\circ} 34^{\prime}$ E; altitude 98 m, in a loamy and clayey soil (Alfic Eutrochrepts);

- Morozzo (44 24' N, $7^{\circ} 43^{\prime}$ E; altitude 431 m, in a medium textured soil (Alfic Dystochrepts);

- Verolengo (45 $11^{\prime}$ N, $7^{\circ} 58^{\prime}$ E; altitude 169 $\mathrm{m}$, in a shallow and sandy soil (Typic Hapludalfs).

The hybrids were strip-test sowed in all the sites. The plot size was $100 \mathrm{~m}$ by 8 rows, and the row spacing was 0.75 . The information relative to the crop practices of the experiment sites is given in table 1.

Three repetition of 100 ears (including the ears used for the evaluation of fungal ear rot incidence and severity and European corn borer damage incidence) were collected in each plot by hand at the end of maturity (moisture content of grains between $20-26 \%$ ) and shelled using an electric sheller. The kernels were mixed thoroughly to obtain a random distribution of the kernels and samples $(5 \mathrm{~kg})$ were taken to analyze the mycotoxin content. These samples were frozen at a temperature of $-18{ }^{\circ} \mathrm{C}$.

\section{Entomological and micological measurements}

The European corn borer (ECB - Ostrinia nubilalis $\mathrm{Hb}$.) damage incidence was evaluated on 3 repetitions of 30 ears from each plot at harvest time. This parameter was calculated as the percentage of ears per plot with injury and kernel damage or apical and basal tunnels in the cob due to larvae activity.

Fungal ear rot incidence and severity were calculated on 3 repetitions of 30 ears from each plot at harvest time. Fungal ear rot incidence was calculated as the percentage of ears per plot with symptoms, while fungal ear rot severity was calculated as the percentage of kernels per ear with symptoms. A scale of 1 to 7 was used in which each numerical value corresponds to a percentage interval of surfaces exhibiting symptoms of the disease according to the following schedule: $1=0 \%, 2=1-3 \%, 3=4-10 \%, 4=11-$ $25 \%, 5=26-50 \%, 6=51-75 \%, 7>75 \%$ (Reid et al., 1999). 
Table 1. General field trial information.

\begin{tabular}{|c|c|c|c|c|c|}
\hline Site & Soil type & $\begin{array}{c}\text { Fertilization } \\
\text { unit }\end{array}$ & $\begin{array}{c}\text { Irrigation } \\
\text { (number and type) }\end{array}$ & Sowing & Harvest \\
\hline Carmagnola (TO) & medium-textured & $\begin{array}{c}\mathrm{N}=200 \\
\mathrm{P}_{2} \mathrm{O}_{5}=80 \\
\mathrm{~K}_{2} \mathrm{O}=80\end{array}$ & $\begin{array}{c}\qquad \begin{aligned} 2000 & =3 \\
2001 & =3 \\
2002 & =2\end{aligned} \\
\text { flowing irrigation }\end{array}$ & $\begin{array}{l}2000=\text { April } 23 \\
2001=\text { April } 21 \\
2002=\text { April } 23\end{array}$ & $\begin{array}{c}2000=\text { October } 5 \\
2001=\text { Sept. } 25 \\
2002=\text { October } 9\end{array}$ \\
\hline Giarole (AL) & $\begin{array}{l}\text { muddy-medium } \\
\text { textured }\end{array}$ & $\begin{array}{c}\mathrm{N}=180 \\
\mathrm{P}_{2} \mathrm{O}_{5}=55 \\
\mathrm{~K}_{2} \mathrm{O}=130\end{array}$ & 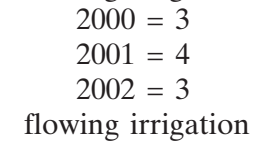 & $\begin{array}{l}2000=\text { May } 17 \\
2001=\text { April } 15 \\
2002=\text { April } 24\end{array}$ & $\begin{array}{c}2000=\text { October } 27 \\
2001=\text { October } 2 \\
2002=\text { October } 6\end{array}$ \\
\hline Morozzo $(\mathrm{CN})$ & medium-textured & $\begin{array}{c}\mathrm{N}=260 \\
\mathrm{P}_{2} \mathrm{O}_{5}=100 \\
\mathrm{~K}_{2} \mathrm{O}=150\end{array}$ & 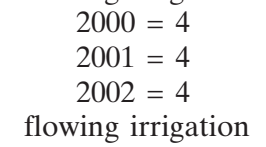 & $\begin{array}{c}2000=\text { May } 4 \\
2001=\text { April } 24 \\
2002=\text { April } 27\end{array}$ & $\begin{array}{l}2000=\text { October } 20 \\
2001=\text { October } 11 \\
2002=\text { October } 16\end{array}$ \\
\hline Verolengo (TO) & sandy & $\begin{array}{c}\mathrm{N}=350 \\
\mathrm{P}_{2} \mathrm{O}_{5}=110 \\
\mathrm{~K}_{2} \mathrm{O}=230\end{array}$ & 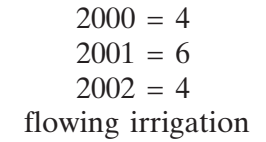 & $\begin{array}{l}2000=\text { April } 26 \\
2001=\text { April } 19 \\
2002=\text { April } 20\end{array}$ & $\begin{array}{c}2000=\text { October } 4 \\
2001=\text { Sept. } 18 \\
2002=\text { October } 2\end{array}$ \\
\hline
\end{tabular}

\section{Mycotoxin analyses}

A $5 \mathrm{~kg}$ representative sample of grain from each plot was freeze-dried and milled. A $50 \mathrm{~g}$ representative sub-sample of the milled material was analysed for mycotoxin content. Mycotoxin analysis was carried out using appropriate HPLC methods for each toxin. All the samples were analysed for fumonisin $\mathrm{B}_{1}$ and zearalenone content.

For fumonisin $\mathrm{B}_{1}, 50 \mathrm{~g}$ samples were extracted by shaking for at least 15 min with 100 $\mathrm{ml}$ of methanol/water $80 / 20$ containing $5 \mathrm{~g}$ of $\mathrm{NaCl}$. The supernatant was filtered through filter paper $(0.45 \mu \mathrm{m})$, diluted with $40 \mathrm{ml}$ of PBS $\left(8.0 \mathrm{~g}\right.$ of $\mathrm{NaCl}+1.2 \mathrm{~g}$ of $\mathrm{Na}_{2} \mathrm{HPO}_{4}+0.2 \mathrm{~g}$ of $\mathrm{KCl}+0.2 \mathrm{~g}$ of $\mathrm{KH}_{2} \mathrm{PO}_{4}$ in $1 \mathrm{l}$ of water), and was cleaned using a FumoniTest column (Vicam ${ }^{\circledR}$ ) by rinsing with $10 \mathrm{ml}$ of PBS. The fumonisin $\mathrm{B}_{1}$ was then eluted using $1.5 \mathrm{ml}$ of methanol and $200 \mu \mathrm{l}$ of methanol/water 50/50. Fluorescent derivates of the fumonisin were formed using 225 $\mu \mathrm{l}$ of OPA (40 mg of o-phthaldialdehyde in 1 $\mathrm{ml}$ of methanol, and a solution $0.1 \mathrm{M}$ of disodium tetraborate and $50 \mu \mathrm{l}$ of 2-mercaptoethanol). $10 \mu \mathrm{l}$ was injected into an HPLC column (Hypersil C18 column, $100 \times 2.1 \mathrm{~mm}, 0.2 \mathrm{ml} \mathrm{min}^{-1}$; fluorescence detector, with an excitation wavelength of $250 \mathrm{~nm}$ and an emission wavelength of 440 $\mathrm{nm})$. Toxin quantification was performed using external standards and peak height measurements. The detection limit was $10 \mu \mathrm{g} \mathrm{kg}^{-1}$.

As far as zearalenone is concerned, $50 \mathrm{~g} \mathrm{sam}-$ ples were extracted by shaking for at least 15 min with $250 \mathrm{ml}$ of chloroform containing $25 \mathrm{~g}$ of diatomaceous earth. The extraction was completed using the AOAC 985.18 method (2005). A $2 \mu \mathrm{l}$ test solution was injected into an HPLC column (Hypersil C18 column, $100 \times 2.1 \mathrm{~mm}, 3$ $\mu \mathrm{m} ; \quad 0.45 \mathrm{ml} \mathrm{min}^{-1} ;$ mobile phase water/(methanol/acetonitrile 4/1) 55/45, fluorescence detector, with an excitation wavelength of $235 \mathrm{~nm}$ and an emission wavelength of $458 \mathrm{~nm}$ ). Toxin quantification was performed as above.

\section{Statistical analysis}

An analysis of variance (SPSS Inc., Chicago, IL, Version 12.0) was utilized to compare European corn borer (ECB) damage incidence, fungal ear rot incidence and severity and the fumonisin $B_{1}$ and zearalenone content, according to Gomez and Gomez (1984). Multiple comparison tests were performed according to the Tukey test on treatment means.

The values of ECB damage incidence, fungal ear rot incidence and severity were previously transformed using $\mathrm{y}^{\prime}=\operatorname{arcsen} \sqrt{ } \mathrm{x}^{*} 180 / \pi$, as percentage data derived from counting.

\section{Results}

The comparison between the different types of commercial hybrids was carried out in years and sites with remarkably different meteorological trends (Tab. 2). The first year was characterised 
Table 2. Rainfall and mean temperature from July to October 2000-2002 in the sites ${ }^{\mathrm{Z}}$ of experimental fields.

\begin{tabular}{|c|c|c|c|c|c|c|c|c|c|c|c|c|}
\hline & \multicolumn{4}{|c|}{2000} & \multicolumn{4}{|c|}{2001} & \multicolumn{4}{|c|}{2002} \\
\hline & $\mathrm{CA}$ & GI & MR & $\mathrm{VE}$ & $\mathrm{CA}$ & GI & MR & $\mathrm{VE}$ & $\mathrm{CA}$ & GI & MR & $\mathrm{VE}$ \\
\hline \multicolumn{13}{|l|}{ Rainfall (mm) } \\
\hline July & 34.8 & 29.2 & 20.8 & 81.4 & 25.0 & 14.8 & 58.0 & 109.2 & 108.0 & 71.6 & 125.6 & 95.2 \\
\hline August & 68.8 & 16.6 & 31.8 & 64.4 & 36.4 & 20.0 & 18.4 & 38.8 & 211.2 & 88.8 & 107.0 & 165.8 \\
\hline September & 168.0 & 27.2 & 106.8 & 186.6 & 37.2 & 43.2 & 38.6 & 50.6 & 204.6 & 40.5 & 87.6 & 108.2 \\
\hline October & 148.0 & 24.2 & 181.2 & 175.4 & 45.4 & 33.8 & 33.4 & 65.8 & 57.8 & 69.4 & 78.0 & 83.2 \\
\hline July-October & 419.6 & 97.2 & 340.6 & 507.8 & 144.0 & 111.8 & 148.4 & 264.4 & 581.6 & 270.3 & 398.2 & 452.4 \\
\hline $\begin{array}{l}\text { Mean } \\
\text { temperature }\left({ }^{\circ} \mathrm{C}\right)\end{array}$ & 18.1 & 19.0 & 18.6 & 18.8 & 18.6 & 19.4 & 18.8 & 19.2 & 17.6 & 18.4 & 17.6 & 18.1 \\
\hline
\end{tabular}

(*) Data from: Carmagnola, Giarole, Morozzo, Verolengo.

by mild temperatures and limited rainfall from the early milk to dough stage (Growth Stage 7383, according to Weber and Bleiholder, 1990; Lancashire et al., 1991) while it was later characterised by heavy rainfall during the final stages of ripening and during harvesting. The second year had higher mean temperatures and more limited rainfall during ripening. The last year was in general cooler and there was frequent rainfall from anthesis to the complete ripening. Carmagnola and Morozzo were the coolest sites with heavier rainfall, while Giarole had higher average temperatures and limited rainfall.

The ECB infestation progressively increased over the three year experimental period, and involved almost all the ears that were collected in 2002 in all the sites. Neither the grain hardness nor the hybrid maturity showed any significant influence of insect activity, in any of the years that were considered (Tab. 3 and 4).

As for ECB incidence, no significant differences were observed for fungal ear rot incidence or severity in function of the grain hardness or the hybrid maturity (Tab. 3 and 4).

The fumonisin $\mathrm{B}_{1}$ and zearalenone contamination for the different hybrid categories is reported in tables 5 and 6 . Fumonisin $\mathrm{B}_{1}$ contamination above the instrumental detection limits concern all the samples; this toxin ranged be-

Table 3. Effect of grain hardness on ECB incidence, Fusarium ear rot incidence and severity, field experiments conducted in 2000-2002 in 4 Piedmont sites $\mathrm{V}$.

\begin{tabular}{|c|c|c|c|c|}
\hline \multirow[t]{2}{*}{ Year } & \multirow[t]{2}{*}{ Grain hardness ${ }^{\mathrm{Z}}$} & \multirow{2}{*}{$\begin{array}{c}\text { ECB incidence }^{\mathrm{W}} \\
\%\end{array}$} & \multirow{2}{*}{$\begin{array}{c}\text { Fusarium ear rot } \\
\text { incidence }^{\mathrm{x}}\end{array}$} & \multirow{2}{*}{$\begin{array}{c}\begin{array}{c}\text { Fusarium ear rot } \\
\text { severity }^{\mathrm{Y}}\end{array} \\
\% \\
\end{array}$} \\
\hline & & & & \\
\hline \multirow[t]{4}{*}{2000} & soft & 84.4 & 56.9 & 2.8 \\
\hline & intermediate & 73.3 & 55.0 & 2.8 \\
\hline & hard & 81.7 & 59.2 & 3.0 \\
\hline & $P$ - value & 0.126 & 0.910 & 0.980 \\
\hline \multirow[t]{4}{*}{2001} & soft & 95.9 & 80.7 & 7.1 \\
\hline & intermediate & 90.8 & 72.3 & 7.7 \\
\hline & hard & 87.0 & 69.3 & 4.5 \\
\hline & $P$ - value & 0.160 & 0.406 & 0.186 \\
\hline \multirow[t]{4}{*}{2002} & soft & 96.7 & 94.7 & 6.4 \\
\hline & intermediate & 98.6 & 92.8 & 5.1 \\
\hline & hard & 95.6 & 90.0 & 4.8 \\
\hline & $P$ - value & 0.151 & 0.309 & 0.202 \\
\hline \multicolumn{5}{|c|}{$\begin{array}{l}\text { v Carmagnola, Giarole, Morozzo, Verolengo. Data reported for each year are mean values of } 4 \text { sites. } \\
\text { w ECB incidence was calculated as the percentage of ears with symptoms, based on } 30 \text { ears per plot. } \\
\text { x Fusarium ear rot incidence was calculated as the percentage of ears with symptoms, based on } 30 \text { ears per plot. } \\
\text { y Fusarium ear rot severity was calculated as the mean percentage of kernel with symptoms per ear, based on } 30 \text { ears per plot. } \\
\mathrm{z} \text { based on the H/S endosperm ratio: soft (values }<1 \text { ); intermediate (values between } 1 \text { and } 4 \text { ), hard (values }>4 \text { ). } \\
\text { The values in the same column followed by the same letter are not significantly different according to the Student-Newman-Keuls } \\
\text { test (ANOVA, P }<0.05 \text { ). }\end{array}$} \\
\hline
\end{tabular}


Table 4. Effect of hybrid maturity on ECB incidence, Fusarium ear rot incidence and severity; field experiments conducted in 2000-2002 in 4 Piedmont sites $^{\mathrm{W}}$.

\begin{tabular}{|c|c|c|c|c|}
\hline \multirow[t]{2}{*}{ Year } & \multirow[t]{2}{*}{$\begin{array}{l}\text { Maturity } \\
\text { (FAO rating) }\end{array}$} & ECB incidence ${ }^{\mathrm{X}}$ & $\begin{array}{c}\text { Fusarium ear rot } \\
\text { incidence }^{\mathrm{Y}}\end{array}$ & $\begin{array}{c}\text { Fusarium ear rot } \\
\text { severity }\end{array}$ \\
\hline & & $\%$ & $\%$ & $\%$ \\
\hline \multirow[t]{4}{*}{2000} & 500 & 80.8 & 52.8 & 2.6 \\
\hline & 600 & 76.9 & 59.7 & 3.0 \\
\hline & 700 & 81.7 & 57.5 & 3.2 \\
\hline & $P$ - value & 0.745 & 0.643 & 0.520 \\
\hline \multirow[t]{4}{*}{2001} & 500 & 89.4 & 69.8 & 6.1 \\
\hline & 600 & 91.1 & 78.2 & 6.1 \\
\hline & 700 & 95.6 & 78.3 & 7.0 \\
\hline & $P$ - value & 0.457 & 0.465 & 0.935 \\
\hline \multirow[t]{4}{*}{2002} & 500 & 97.2 & 93.0 & 5.8 \\
\hline & 600 & 95.7 & 91.0 & 5.4 \\
\hline & 700 & 99.3 & 96.0 & 5.1 \\
\hline & $P$ - value & 0.190 & 0.456 & 0.768 \\
\hline \multicolumn{5}{|c|}{$\begin{array}{l}\text { w Carmagnola, Giarole, Morozzo, Verolengo. Data reported for each year are mean values of } 4 \text { sites. } \\
\text { x ECB incidence was calculated as the percentage of ears with symptoms, based on } 30 \text { ears per plot. } \\
\text { Y Fusarium ear rot incidence was calculated as the percentage of ears with symptoms, based on } 30 \text { ears per plot. } \\
{ }^{2} \text { Fusarium ear rot severity was calculated as the mean percentage of kernel with symptoms per ear, based on } 30 \text { ears per plot. } \\
\text { The values in the same column followed by the same letter are not significantly different according to the Student-Newman-Keuls } \\
\text { test (ANOVA, } \mathrm{P}<0.05 \text { ). }\end{array}$} \\
\hline
\end{tabular}

tween 145 and $5079 \mu \mathrm{g} \mathrm{kg}^{-1}$ in 2000 , between 380 and $6559 \mu \mathrm{g} \mathrm{kg}^{-1}$ in 2001 and between 1262 and $5357 \mu \mathrm{g} \mathrm{kg}^{-1}$ in 2002. Zearalenone was found in concentrations above the instrumental detection limits in $39.3,12.5$ and $91.4 \%$ of the samples taken in 2000, 2001 and 2002, respectively. The maximum value of contamination recorded each year was $118 \mu \mathrm{g} \mathrm{kg}^{-1}$ in $2000,40 \mu \mathrm{g} \mathrm{kg}^{-1}$ in 2001 and $340 \mu \mathrm{g} \mathrm{kg}^{-1}$ in 2002 .

Every year, the grain hardness has significantly influenced fumonisin $\mathrm{B}_{1}$ content with a $50 \%$ lower mean contamination of the hard endosperm hybrids than the soft (Tab. 5). The intermediate endosperm hybrids always had values of this toxin higher than the hard grain varieties, but the differences were always not significant.

The zearalenone content never resulted to be significantly different in function of the grain hardness of the hybrids.

The presence of fumonisin $\mathrm{B}_{1}$ in the grain of different maturity hybrids only resulted to be significantly different in 2001, with a mean concentration 2 times higher in the later hybrids (FAO rating 700) compared to the medium and medium-late hybrids (Tab. 6).

The influence of the hybrid maturity on the zearalenone contamination was instead clearly
Table 5. Effect of grain hardness on fumonisin B1 and zearalenone concentration; field experiments conducted in 2000-2002 in 4 Piedmont sites ${ }^{\mathrm{Y}}$.

\begin{tabular}{llrr}
\hline Year & $\begin{array}{l}\text { Grain } \\
\text { hardness }\end{array}$ & $\begin{array}{r}\text { Fumonisin } \mathrm{B}_{1} \\
\left(\mu \mathrm{kg}^{-1}\right)\end{array}$ & $\begin{array}{r}\text { Zearalenone } \\
(\mu \mathrm{g} \mathrm{kg})\end{array}$ \\
\hline 2000 & soft & $2677 \mathrm{a}$ & 23 \\
& intermediate & $1420 \mathrm{~b}$ & 29 \\
& hard & $872 \mathrm{~b}$ & 25 \\
& $P$ - value & 0.003 & 0.912 \\
\hline 2001 & soft & $3573 \mathrm{a}$ & 8 \\
& intermediate & $2658 \mathrm{ab}$ & 8 \\
& hard & $1553 \mathrm{~b}$ & 5 \\
& $P$ - value & 0.045 & 0.510 \\
\hline 2002 & soft & $4180 \mathrm{a}$ & 42 \\
& intermediate & $3693 \mathrm{ab}$ & 128 \\
& hard & $3141 \mathrm{~b}$ & 114 \\
& $P$ - value & 0.038 & 0.055 \\
\hline
\end{tabular}

${ }^{Y}$ Carmagnola, Giarole, Morozzo, Verolengo. Data reported for each year are mean values of 4 sites.

$\mathrm{Z}$ based on the H/S endosperm ratio: soft (values $<1$ ); intermediate (values between 1 and 4),hard (values $>4$ ).

The values in the same column followed by the same letter are not significantly different according to the Student-NewmanKeuls test (ANOVA, $\mathrm{P}<0.05$ ).

observed in 2001 and 2002. Contamination of the class 500 hybrids was significantly lower (by $66 \%$ ) than the class 700 hybrids. Contamination of the class 500 and class 600 hybrids was only significantly different in 2001 ( $+41 \%$ for the later hybrids). 
Table 6. Effect of hybrid maturity on fumonisin $\mathrm{B}_{1}$ and zearalenone concentration; field experiments conducted in 2000-2002 in 4 Piedmont sites ${ }^{\mathrm{Z}}$.

\begin{tabular}{llrr}
\hline Year & $\begin{array}{l}\text { Maturity } \\
(\text { FAO rating })\end{array}$ & $\begin{array}{r}\text { Fumonisin } \mathrm{B}_{1} \\
\left(\mu \mathrm{kg}^{-1}\right)\end{array}$ & $\begin{array}{r}\text { Zearalenone } \\
(\mu \mathrm{g} \mathrm{kg})\end{array}$ \\
\hline 2000 & 500 & 2152 & 23 \\
& 600 & 1699 & 27 \\
& 700 & 1609 & 30 \\
& $P$ - value & 0.591 & 0.947 \\
\hline 2001 & 500 & $2179 \mathrm{~b}$ & $5 \mathrm{~b}$ \\
& 600 & $2082 \mathrm{~b}$ & $6 \mathrm{~b}$ \\
& 700 & $4410 \mathrm{a}$ & $16 \mathrm{a}$ \\
& $P$ - value & 0.023 & 0.003 \\
\hline 2002 & 500 & 3223 & $63 \mathrm{c}$ \\
& 600 & 3686 & $102 \mathrm{~b}$ \\
& 700 & 3960 & $173 \mathrm{a}$ \\
& $P$ - value & 0.611 & 0.030
\end{tabular}

${ }^{\mathrm{z}}$ Carmagnola, Giarole, Morozzo, Verolengo. Data reported for each year are mean values of 4 sites.

The values in the same column followed by the same letter are not significantly different according 5 to the Student-NewmanKeuls test (ANOVA, $\mathrm{P}<0.05$ ).

\section{Discussion}

The collected data highlighted the presence of differences between the maize hybrids tested for contamination to fumonisins and zearalenone, which resulted to be regulated by different variety characteristics.

No difference were observed for fungal ear rot incidence and severity. Several authors reported that mycotoxins are not clearly related to ear rot symptoms (Stewart et al., 2002; Munkvold et al., 2003b): toxins are very stable compounds and they could remain in grains also after the mould death. On the other hand not all the mould are able to produce mycotoxins (Bottalico, 1999).

The comparison between hybrids with different maturity showed that the zearalenone contamination can be remarkably reduced with the cultivation of early maturing hybrids, thus confirming data by Reid and Sinha (1998) and Bata et al. (2001). The later hybrids, with the use of FAO class 700 hybrids for the production of maize grain in the Po Plain, have generally high zearalenone contamination, according to AA.VV. (2004). The differences between the late maturing hybrids (FAO rating 700) and the mediumearly (FAO rating 500) or medium-late maturing hybrids (FAO rating 600) were higher in 2002 , which was the year with the heaviest rain- fall and coolest temperatures, and this caused a longer crop thriving and an extended duration of the ripening stages. The presence of zearalenone in the grain in the dryer 2000 and 2001, was rather reduced but it however always affected the later maturing hybrids in the different sites. This toxin was instead found in hybrids rated at FAO 500 and 600 maturity only in some hybrids in the wetter environments. The difference between late and early maturing hybrids is probably not related to the different conditions during infection, which for $F$. graminearum, is primary by silks during the first 6 days after silk emergence (Reid and Hamilton, 1996), but to the conditions in which ripening occurs. Gibberella ear rot development is favoured by moderate temperatures, high rainfall and humid conditions during the maturation period (Sutton et al., 1980; Munkvold, 2003b) and this occurs more frequently for late maturing hybrids. Moreover, Reid and Sinha (1998) suggest that $F$. graminearum may not spread to additional kernels once drying and hardening of the kernels has started, and this occurs before for earlier maturing genotypes.

Fumonisins, instead, were confirmed to occur ubiquitously in maize-producing areas (Shephard et al., 1996; AA.VV., 2005). These toxins do not seem to be primarily influenced by hybrid maturity, confirming data by Ramirez et al., (1996) and Camargos et al. (2001), but rather by grain hardness or by some other kernel characteristics that provide physical barriers to ear infection, according to Hoenisch and Davis (1994). The present data suggest that hard endosperm kernels, thanks to their texture, are more resistant than soft kernels to fumonisin contamination. The lower susceptibility of hard hybrids could be connected both to a greater hardness and density of the endosperm fraction that could be a less susceptible substrate to toxinogenesis and to a more compact pericarp which is a more effective physical barrier to fungal infection, as suggested by Costa et al. (2003).

Moreover, F. verticillioides infection and Fusarium ear rot severity are closely correlated to insect injury, primarily due to $O$. nubilalis (Bakan et al., 2002; Alma et al., 2005), and this appears to be the most important infection pathway in the Po Plain area. Kernels with hard pericarps may have the ability to avoid grain injury and reduce disease development and my- 
cotoxin production. De la Campa et al. (2005) reported that some hybrids are more susceptible to insect damage than others and a significant interaction exists between insect injury susceptibility of hybrids and fumonisin accumulation.

Apart from the lower severity of infection from fungal species in the field, it should also be considered that harder grains show less breaking and cracking after harvesting (Stroshine et al., 1986), thus ensuring lower contamination risks, even from other mycotoxins, during storage (Magan et al., 2003, Paulsen et al., 2003).

If some hybrids that showed a high contamination risk for both toxins are excluded, the analysed hybrids generally show an inverse relation due to the presence of the two toxins in the grain. There are therefore some hybrids that are more susceptible to contamination from zearalenone, but generally more resistant to fumonisins, while others are characterised by a higher susceptibility to contamination from fumonisin $\mathrm{B}_{1}$ and a higher resistance to zearalenone.

In conclusion, this research stress the role of kernel endosperm and of the hybrid maturity class on mycotoxin contamination.

Prolonged ripening has proved to be important for zearalenone contamination; for this reason, late maturing hybrids (FAO 600 and 700) are potentially more at risk in the Po plain area. Most of the contamination of late maturing hybrids, compared to early-medium maturing hybrids, is more obvious in the environments and years that favour a greater vegetative growth of the crop. Grain endosperm hardness has not shown any effect on the presence of zearalenone.

The presence of fumonisins is not strictly correlated with hybrid maturity but rather with the physical properties of the endosperm of the grain. Soft hybrids are more prone to contamination from these toxins, while an increase in the endosperm hardness reduces the concentration of fumonisin $B_{1}$ in the grain.

In conclusion, the results that were obtained have shown clear differences in susceptibility to Fusarium toxin contamination among the yellow dent commercial hybrids.

In the near future it is essential to obtain, through genetic improvement, hybrids that can guarantee low risks of contamination for a wider range of toxins; however, at the moment the variety choices in the farm should be oriented towards privileging a reduced content of few mycotoxins or the one which results to be more critical with final use of the product.

In order to reach this objective, the choice of hybrid should always be coupled together with all those good agricultural practices that are able to reduce the risk of encountering a high mycotoxin content and therefore to increase the health quality of the production.

\section{Acknowledgements}

The authors would like to thank Laura Bersani and Luca Minelli for their expert technical assistance. Found for this research were provided from grants from the Piedmont Region - Assessorato Agricoltura.

\section{References}

AA.VV. 2004. Impiego di tecniche agronomiche per contenere le micotossine nella granella di mais. L'Informatore Agrario, 6:45-50.

AA.VV. 2005. La diffusione delle micotossine nelle produzioni italiane di mais. L'Informatore Agrario, 10:47-51.

Abbas H.K., Williams W.P., Windham W.G.L., Pringle H.C., Xie W., Shier W.T. 2002. Aflatoxin and fumonisin contamination of commercial corn (Zea Mays) hybrids in Mississippi. J. Agric. Food Chem., 50:52465254.

Alma A., Lessio F., Reyneri A., Blandino M. 2005. Relationships between Ostrinia nubilalis Hübner (Lepidoptera Pyraustidae), crop technique and mycotoxin contamination of corn kernel in northwestern Italy. Int. J. Pest Manag., 51,3:165-173.

Assabgui R.A., Reid L.M., Hamilton R.I., Arnason J.T. 1993. Correletion of kernel (E)-Ferulic acid content of maize with resistance to Fusarium graminearum. Phytopathology, 83:949-953.

Bacon C.W., Nelson P.E. 1994. Fumonisin production in corn by toxigenic strains of Fusarium moniliforme and Fusarium proliferatum. J. Food Prot., 57:514-521.

Bakan B., Melcion D., Richard-Molard D., Cahagnier B. 2002. Fungal growth and Fusarium mycotoxin content in isogenic traditional maize and genetically modified maize growth in France and Spain. Journal of Agricoltural and Food Chemistry, 50:728-731.

Bata A., Rafai P., Kovacs G. 2001. Investigation and a new evaluation method of the resistance of maize hybrids grown in Hungary to Fusarium moulds. J. Phytopathology, 149:107-111.

Blacwell B.A., Gilliam J.T., Savard M.E., Miller J.D., Du- 
vick J.P. 1999. Oxidative deamination of hydrolyzed fumonisin B1 (AP1) by culture of Exophiala spinifera. Nat. Toxins, 7:31-38.

Blandino M., Reyneri A. 2007. Comparision between normal and waxy maize hybrids for Fusarium-toxin contamination in NW Italy. Maydica, 52, 2:127-134.

Bilgrami K.S., Choudhary A.K. 1998. Mycotoxins in preharvest contamination of agricultural crops. In: Sinha K.K., Bhatnagar D. (eds.): Mycotoxins in Agriculture and Food Safety, 1-43, Marcel Dekker, New York.

Bottalico A. 1999. Muffe e micotossine delle granaglie. Tecnica Molitoria, 12:195-219.

Brown R.L., Bhatnagar D., Cleveland T.E., Cary J.W. 1998. Recent advances in preharvest prevention of mycotoxin contamination. In: Sinha K.K., Bhatnagar D. (eds.): Mycotoxins in Agriculture and Food Safety, 381-398, Marcel Dekker, New York.

Brown R.L., Chen Z.Y., Cleveland T.E., Russin J.S. 1999. Advances in the development of host resistance in corn to aflatoxin contamination by Aspergillus flavus. Phytopathology, 89:113-117.

Butròn A., Stantiago R., Mansilla P., Pintos-Varela. C., Ordàs A., Malvar R.A. 2006. Maize (Zea mays L.) genetic factors for preventing fumonisin contamination. J. Agric. Food Chem., 54:6113-6117.

Camargos S.M., Valente Soares L.M., Savazaki E., Bolonhezi D., Castro J.L., Bortolleto N. 2001. Accumulation of fumonisins $B_{1}$ and $B_{2}$ in freshly harvested Brazilian commercial maize at three locations during two nonconsecutive seasons. Mycopathologia, 155:219-228.

Chelkowski J. 1998. Distribution of Fusarium species and their mycotoxins in cereal grains. In: Sinha K.K., Bhatnagar D. (eds.): Mycotoxins in Agriculture and Food Safety, 45-64, Marcel Dekker, New York.

Chungu C., Mather D.E., Reid L.M., Hamilton R.I. 1996. Comparision of techniques for inoculating silk, kernel and cob tissues with Fusarium graminearum. Plant Dis., 80:81-84.

Clemens M.J., Kleinschmidt C.E., Maragos C.M., Pataky J.K., White D.G. 2003. Evaluation of inocuation techniques for Fusarium ear rot and fumonisin contamination of corn. Plant Dis., 87:147-153.

Costa R.S., Môro F.V., Môro J.R, Da Silva H.P., Panizzi R.D.C. 2003. Relação entre características morfológicas da cariopse e fusariose em milho. Pesq. agropec. bras. Brasília, 1, 38:27-33.

De La Campa R., Hooker D.C., Miller J.D., Schaafsma A.W., Hammond B.G. 2005. Modeling effects of environment, insect damage and Bt genotypes on fumonisin accumulation in maize in Argentina and the Philippines. Mycopathologia, 159:539-552.

D'Mello J.P.F., MacDonald A.M.C. 1997. Mycotoxins. Animal Feed Science Technology, 69:155-166.

Dutton M.F. 1996. Fumonisins, mycotoxins of increasing importance: their nature and their effects. Pharmacol. Ther., 70, 2:137-161.
Duvick J.P., Rood T., Rao A.G., Marshak D.R. 1992. Purification and characterization of a novel antimicrobial peptide from maize (Zea mays L) kernels. J. Biol. Chem., 267:18814-18820.

Duvick J. 2001. Prospects for reducting fumonisin contamination of maize through genetic modification. Environ. Health Perspect., 109:337-342.

Enerson P.M., Hunter R.B. 1980. Response of maize hybrids to artificially inoculated ear mold incited by Gibberella zeae. Can. J. Plant Sci., 60:60-63.

Gomez K.A., Gomez A.A. 1984. Statistical procedures for agricultural research. $2^{\text {th }}$ ed. John Wiley \& sons, Inc. New York.

Gorman D.P., Kang M.S., Cleveland T., Hutchinson R.L. 1992. Combining ability for resistance to field aflatoxin accumulation in maize grain. Plant Breed., 109:292-303.

Hamblin A.M., White D.G. 2000. Inheritance of resistance to Aspergillus ear rot and aflatoxin production of corn from Tex6. Phytopathology, 90:292-296.

Headrick J.M., Pataky J.K. 1991. Maternal influence on the resistance of sweet corn lines to kernel infection by Fusarium moniliforme. Phytopathology, 81:268274.

Hoenisch R.W., Davis R.M. 1994. Relationship between kernel pericarp thickness and susceptibility to Fusarium ear rot in field corn. Plant Dis., 78:578-580.

Hussein H.S., Brasel J.M. 2001. Toxicity, metabolism, and impact of mycotoxins on humans and animals. Toxicology, 167:101-134.

Jacobsen B.J., Bowen K.L., Shelby R.A., Diener U.L., Kemppainen B.W. 2002. Mycotoxins and mycotoxicoses. Circular ANR-767, Auburn University, Auburn, Alabama.

Kleinschmidt C.E., Clements M.J., Maragos C.M., Pataky J.K., White D.G. 2005. Evaluation of food-grade dent corn hybrids fro severity of Fusarium ear rot and fumonisin accumulation in grain. Plant Dis., 89:291-297.

Koehler B. 1959. Corn ear rots in Illinois. Page 85 in: Univ. Ill. Agric. Exp. Stn. Bull. 639.

Lancashire P.D., Bleiholder H., Longelüddcke P., Stauss R., Van Den Boom T., Weber E., Witzenberger A. 1991. An uniform decimal code for growth stages of crops and weeds. Ann. Appl. Biol., 119:561-601.

Li P.X.-P., Hardacre A.K., Campanella O.H., Kirkpatrick K.J. 1996. Determination of endosperm characteristics of 38 corn hybrids using the Stenvert hardness test. Cereal Chem., 73,4:466-471.

Logrierco A. 2001. Aspetti della contaminazione da funghi tossigeni e micotossine nelle derrate alimentari. L'Informatore fitopatologico, 6:55-57.

Magan N., Hope R., Cairns V., Aldred D. 2003. Post-harvest fungal ecology: impact of fungal growth and mycotoxin accumulation in stored grain. European Journal of Plant Pathology, 109:723-730.

Manka M., Chelkowski J., Brayford D., Visconti A., Knasna H., Perkowski J. 1989. Fusarium graminearum 
Schwabe (Teleomorph Schw. Petch) - cultural characteristics, pathogenicity towards cereal seedlings Gibberella zeae and ability to produce mycotoxins. J. Phytopathology, 124:143-148.

Masoero F., Meschini M., Rossi F., Grandini A., Pietri A. 1999. Nutritive value, mycotoxin contamination and in vitro rumen fermentation of normal and genetically modified corn $(\mathrm{Cry} 1 \mathrm{~A}(\mathrm{~B}))$ grown in northern Italy. Maydica, 44:205-209.

Miedaner T. 2004. Plant breeding as a tool for reducing mycotoxins in cereals. In: Meeting the mycotoxin menace. In: Barug D., van Egmond H., Lopez-Garcia R., van Osenbruggen T., Visconti A. (eds.): Meeting the mycotoxin menace, 89-111, Wageningen Academic Publishers, The Netherlands.

Moretti A., Corazza L., Balmas V., Santori A., Ritieni A. 2003. Funghi tossigeni e micotossine: filiera cerealicola. L'Informatore fitopatologico, 12:17-22.

Munkvold G.P., Hellmich R.L., Showers W.B. 1997. Reduced Fusarium ear rot and symptomless infection in kernels of maize genetically engineered for European corn borer resistance. Phytopathology, 87:1071-1077.

Munkvold G.P., Hellmich R.L., Rice L.G. 1999. Comparison of fumonisin concentrations in kernels of transgenic Bt maize hybrids and nontransgenic hybrids. Plant Dis., 83:130-138.

Munkvold G.P. 2003a. Cultural and genetic approaches to managing mycotoxins in maize. Annu. Rev. Phytopathol., 41:99-116.

Munkvold G.P. 2003b. Epidemiology of Fusarium diseases and their mycotoxins in maize ears. European Journal of Plant Pathology, 109:705-713.

Nicholson P., Gosman N., Draeger R., Steed A. 2004. Control of Fusarium and Aspergillus species and associated mycotoxins on wheat and maize. In: Barug D., van Egmond H., Lopez-Garcia R., van Osenbruggen T., Visconti A. (eds.): Meeting the mycotoxin menace, 113-132, Wageningen Academic Publishers, The Netherlands.

Okubara P.A., Blechl A.E., Mccormick S.P., Alexander N.A., Dill-Macky R., Hohn T.M. 2002. Engineering deoxynivalenol metabolism in wheat through the expression of a fungal trichothecene acetyltransferase gene. Theor. Appl. Genet., 106:74-83.

Payne G.A. 1999. Ear and kernel rots. In: White D.G. (ed.): Compendium of Corn diseases, 44-47, The American Phytopathological Society, St. Paul, MN.

Pascale M., Visconti A., Chelkowski J. 2002. Ear rot susceptibility and mycotoxins contamination of maize hybrids inoculated with Fusarium species under field conditions. European Journal of Plant Pathology, 108:645-651.

Paulsen R.M, Watson A.W., Singh M. 2003. Measurement and maintenance of corn quality. In: White P.J., Johnson L.A. (eds.): Corn: Chemistry and Technology, $2^{\text {nd }}$ Edition, 35-68, American Association of Cereal Chemists, Inc., St. Paul, MN.

Pietri A., Bertuzzi T., Pallaroni L., Piva G. 2004. Occur- rence of mycotoxins and ergosterol in maize harvested over 5 years in Northern Italy. Food Additives and Contaminants, 21,5:479-487.

Ramirez M.L., Pascale M., Chulze S., Renoso M.M., March G., Visconti A. 1996. Natural occurence of fumonisins and their correlation to Fusarium contamination in commercial maize hybrids growth in Argentina. Mycopathologia, 135:29-34.

Reid L.M., Mather D.E., Hamilton R.I., Bolton A.T. 1992. Genotypic differences in the resistance of maize silk to Fusarium graminearum. Can. J. Plant Pathol., 14:211-214.

Reid L.M., Mather D.E., Bolton A.T., Hamilton R.I. 1994. Evidence for a gene for silk resistance to Fusarium graminearum Schw. ear rot of maize. Journal of Heredity, 85:118-121.

Reid L.M., Hamilton R.I. 1996. Screening maize for resistance to Gibberella ear rot. Agricolture and AgriFood Canada Technical Bulletin 1996-5E.

Reid L.M., Sinha R.C. 1998. Maize maturity and the development of Gibberella ear rot symptoms and deoxynivalenol after inoculation. European Journal of Plant Pathology, 104:147-154.

Reid L.M., Nicol R.W., Ouellet T., Savard M., Miller J.D., Young J.C., Stewart D., Schaafsma A.W. 1999. Interaction of Fusarium graminearum and F. moniliforme in maize ears: disease progress, fungal biomass, and mycotoxin accumulation. Phytopathology, 89:10281037.

Ross P.F., Nelson P.E., Richard J.L., Osweiler G.D., Rice L.G., Plattner R.D., Wilson T.M. 1990. Production of Fumonisins by Fusarium moniliforme and Fusarium proliferatum Isolates Associated with Equine Leukoencephalomalacia and a Pulmonary Edema Syndrome in Swine. Applied and Environmental Microbiology 56,10:3225-3226.

Scott G.E., King S.B. 1984. Site of action of factor for resistance to Fusarium moniliforme in maize. Plant Dis., 68:804-806.

Schaafsma A.W., Nicol R.W., Reid L.M. 1997. Evaluating commercial maize hybrids for resistance to gibberella ear rot. European Journal of Plant Pathology, 103:737-746.

Shephard G.S., Thiel P.G., Stockenstrom S.S., Sydenham E.W. 1996. Worldwide survey of fumonisin contamination of corn and corn based products. Journal of AOAC International, 79,3:671-687.

Snijder C.H.A. 1994. Breeding for resistance to Fusari$u m$ in wheat and maize. In: Miller J.D., Trenholm H.L. (eds.): Mycotoxins in grain: Compounds Other Than Aflatoxin, 37-53, Eagan Press, St. Paul, Minn.

Stewart D.W., Reid L.M., Nicol R.W., Schaafsma A.W. 2002. A mathematical simulation of growth of Fusarium in maize ears after artificial inoculation. Phytopathology, 92:534-541.

Stroshine R.L., Kirleis A.W., Tuite J.F., Bauman L.F., Emam A. 1986. Differences in corn quality among selected corn hybrids. Cereal Foods World, 31:311-316. 
Sutton J.C., Baliko W., Funnell H.S. 1980. Relation of weather variables to incidence of zearal4enone in southern Ontario. Can. J. Plant Sci., 60:149-155.

Sutton J.C. 1982. Epidemiology of wheat headblight and maize ear rot caused by Fusarium graminearum. Can. J. Plant Pathol., 4:195-209.

Vigier B., Reid L.M., Dwyer L.M., Stewart D.W., Sinha R.C., Arnason J.T., Butler G. 2001. Maize resistance to gibberella ear rot: symptoms, deoxynivalenol and yield. Can. J. Plant Pathol., 23:99-105.

Visconti A., Chelkowski J., Solfrizzo M., Bottalico A. 1990. Mycotoxins in corn ears naturally infected with Fusarium graminearum and F. crookwellense. Can. J. Plant Pathol., 12:187-189.

Visconti A., Marasas W.F.O., Miller J.D., Riley R. 1999. Mycotoxins of growing interest: fumonisins. Third Joint FAO/WHO/UNEP International Mycotoxin contamination in foods and feeds, Tunis March 3-6. (Online). Available: www.fao.org/waicent/faoinfo/economic/esn/mycoto/mycoto.htm
Voss K.A., Riley R.T., Norred W.P., Bacon C.W., Meredith F.I., Howard P.C., Plattner R.D., Collins T.F.X., Hansen D.K., Porter J.K. 2001. An overview of rodent toxicities: liver and kidney effects of fumonisins and Fusarium moniliforme. Environmental Health Perspective, 109,2:259-266.

Warfield C.Y., Davis R.M. 1996. Importance of the husk covering on the susceptibility of corn hybrids to Fusarium ear rot. Plant Dis., 80:208-210.

Warren H.L. 1978. Comparision of normal and high-lisine maize hybrids for resistance to kernel rot caused by Fusarium moniliforme. Phytopathology, 68:1331-1335.

Weber E., Bleiholder H. 1990. Erläuterunger zu den BBCH-Dezimal-Codes für die Entwicklungsstadien von Mais, Raps, Faba-Bohne, Sonnenblume und Erbse - mit Abbildungen. Gesunde Pflazen, 42:308-321.

Woloshuk G.L., Fakhoury A. 2000. Novel inhibitor for controlling Aspergillus flavus growth and aflatoxin production on corn. Proceedings Aflatoxin/Fumonisin Workshop. U.S. Dep. Agric. Res. Serv., Washington, DC., 103. 